\title{
EMPIRICAL STUDY OF THE SPIRITUAL POTENTIAL OF THE PERSONALITY OF A PSYCHOLOGIST
}

\section{Olena Danilova ${ }^{1}$ \\ Olga Shcherbliuk ${ }^{2}$}

DOI: https://doi.org/10.30525/978-9934-26-050-6-41

The urgency of the problem In modern society, the issue of human education, self-improvement, spiritual and personal growth is particularly acute. The study of the concept of «Spiritual potential» of the individual is to systematize information about Spirituality from various sources, to describe its phenomenological manifestations; study of the holistic phenomenon of man in connection with the formation - «space-existence and development of the human soul», consideration of the usual categories in the tone of new methodological guidelines; recognition of the diversity, contradictions, complexity of man and his inner life; The research is based on the methodology of the philosophical and theological aspect, the historical and psychological aspect, and the conducted empirical research among students of psychology. is that at the moment in Ukraine we see that valued professional psychologists in various fields who are able to perform a variety of professional duties at a high level.

The aim of the study. It consists in determining the factors of spiritual potential and personal qualities of future psychologists while studying at the university.

Research methods: hermeneutics method, introspection method, conversation, content analysis, longitude, synthesis, generalization.

Methods of research: «Balanced Emotional Empathy Scale» (BEES) by Albert Mehrabian (Albert Mehrabian) and modified by N. Epstein; Kenneth Thomas Questionnaire «Identifying Ways to Conflict Management»; «Methods of assessing the level of camaraderie» V.F. Rakhivsky; author's questionnaire «Striving for Light» is devoted to the spiritual and personal growth of a psychologist.

Interest in the study of the mechanisms of formation and development of personal qualities can be traced in a number of psychological studies by such authors as: I.G. Belyavsky, T.D. Zenkevich-Evstigneeva, I.N. Andreeva, O.F. Bondarenko, I.V. Vachkova, S.P. Derevyanko, E.P. Ilyinim, M. Aminov, O. Bodalova, O. Vlasova, V. Karandasheva, O. Sannikova, N. Chepeleva and others. K. Abulkhanova-Slavska, S. Maksymenko, V. Maskolenko,

\footnotetext{
${ }^{1}$ Mechnikov Odessa National University, Ukraine

${ }^{2}$ Mechnikov Odessa National University, Ukraine
} 
S. Rubenstein, O.S. Danilova considered and emphasize the need to increase the subjectivity of life. According to the scientist Savchin M.V.: «The spiritual potential of a person is a set of his spiritual, mental (mental) and physical strengths and properties that determine his relationship with God, people and the world and his life. A person with high spiritual potential who has a dogmatic consciousness... The main meaning of his life is to improve himself and the world...» [4].

Our interest in the problem of spiritual potential of modern youth is caused primarily by its complexity. No psychological problem has received as wide and comprehensive attention as Spirituality, and no problem has as many «white spots» as the problem of Spirituality [2].

That is why we conducted a study on the basis of ONU named after I.I. Mechnikov, as for many years he has been a high level of training of specialists who are successfully implemented in practice and research. It was attended by 65 recipients aged 15 to 25, students of the socio-economic college of ONU and students of the FPSR.

As a result of the study, we can say that only a small number of recipients $2 \%$ learn to support fashion trends and to maintain the prestige of the social niche, and this can only please us.

According to our goal, we chose and applied the method «Scale of emotional response» A. Megrabyan found the following results in our recipients: $37.5 \%$ - a very high level of empathy; $46.8 \%$ - high level of empathy; $12.5 \%$ - normal level of empathy; $3.1 \%$ - low level of empathy. The high level of emotional response that prevails in our recipients, in our opinion, exposes one of the facets of the spiritual potential of man - empathy, which should be present in future psychologists who will work in the future within the concept of «man-to-man». Based on the results, we concluded that the recipients as future professionals have a risk of professional «burnout».

Conducting a survey of Kenneth Thomas «Determining ways to resolve conflicts, we obtained the following results, the average score for each type: rivalry - $15.6 \%$; cooperation $-84.3 \%$; compromise $-68.75 \%$; avoidance $50 \%$; adaptation $-31.25 \%$. Which confirms our hypothesis that a psychologist should be sensitive, empathetic, non-conflicting, able to cooperate with the environment.

Applied the following method of V.F. Rakhiv «Methods of assessing the level of sociability» we obtained the following results which show that the recipients are very communicative. And their sociability is not so painful, which is also important for our study. According to the result of the author's questionnaire, the following results were obtained. The predominant answer to our open-ended questions was: get education $87.5 \%$, understand the world - 
$62.5 \%$, help others $53.1 \%$, help yourself $-40.6 \%$, society «37.5\%, to make the world better $-34.3 \%$, to help relatives $-25 \%$,» business ideas» $-3.1 \%$.

The results on the second question are as follows: equilibrium $-96.8 \%$; intellectual abilities - 87.5\%; empathy (sensitive, sensual, compassionate) 68.7\%; cheerfulness (positive mood) - 46.8\%; Spiritual (conscious) - 21.9\%; good-natured - 15.6\%; volitional qualities (discipline, patience, endurance) $12.4 \%$; loves his job - 9.37\%; experienced $-9.37 \%$; creative $-9.37 \%$; as well as one answer: charming, flexible, confident, open, with a good sense of humor, self-respecting.

The obtained results were analyzed by the method of content analysis, which gives us the right to draw the following conclusions that the priority of spiritual potential is found in each, but in the «embryonic» state.

In our opinion, the spiritual state of the psychologist's personality was characterized by such qualities as: balance; general intelligence; impassivity; ability to maintain contacts, ie stress resistance in the process of communication; the ability to control their behavior, is to maintain emotional self-control in the process of communication; attraction (attractiveness); congruence; emotional contagion; empathy; cheerfulness. These qualities fundamentally affect a person's mental health, optimize his life, lead to mental and personal development. For their functioning the soul (psyche, personality) needs energy, the source of which is the Spiritual sphere as an inexhaustible source.

\section{References:}

1. Danilova O.S. «Social concept» of the icon-indicator of spirituality: experimental research / O.S. Danilova // Bulletin of the Odessa National University // Bulletin of the Odessa National University. - 25/12/2007. - Volume 12, Issue 16: Psychology, pp. 4-11.

2. Danilova E.S., Shchebliuk O.I. The phenomenon of spiritual growth of modern youth // Man and environment, trends and prospects. Abstracts of III International Scientific and Practical Conference/ SH SCW «NEW ROUTE» Tokyo, Japan. 2020, pp. 191-193.

3. Ovsyanetska L.P. To the problem of psychological essence of personality claims / L.P. Ovsyanetska // Philosophy, sociology, psychology. - Ivano-Frankivsk: Prykarpattia University named after V. Stefanika, 1999. - Vol. 3. - No. 1. - 55-62 pp.

4. Savchin M.V. Spiritual potential of the person (Educational edition): [monography]. - View. 2nd, lane, ext. - Ivano-Frankivsk: City of NV, 2010. - 508 p. 